IJ§ER

ISSN: 2149-5939
International Journal of Social Sciences and Education Research

Online, http://dergipark.gov.tr/ijsser

Volume: 1(1), 2015

\title{
Appreciative inquiry as a means of intra-institutional communication ${ }^{1}$
}

Murat Seyfi²

Received Date: $01 / 01 / 2015$

\author{
Deniz Güven³
}

Accepted Date: $01 / 02$ / 2015

\begin{abstract}
Concrete measurable values such as transparency, information sharing, institutional commitment and effective leadership may be obtained through intra-institutional communication. Brochures, journals, letters, posters, computer technologies, suggestion boxes, educational activities and communication means such as social media are widely used for obtaining these results. Due to an ever-changing and ever-developing world order, the sociological, cultural and psychological structures of the organizations also change and develop. Thus, improving intrainstitutional communication methods and providing new resources for intra-institutional communication studies are vital necessities. Within this context, appreciative inquiry may be defined as an efficient and new method to increase and develop intra-institutional communication resources. Appreciative inquiry is a process aimed at finding the best for people, organizations and their environment. Within this process, every member of the institution has the right to speak and a great value is attached to continuity and inventiveness during the changing process. This study is to reveal the relationship between the principles of appreciative inquiry and the purposes of intrainstitutional communication. In this study documental review was made using qualitative research method. In the light of the information received, the relationship between the principles of appreciative inquiry and the purposes of intra-institutional communication was revealed and usage of appreciative inquiry as a means of intra-institutional communication was suggested.
\end{abstract}

Keywords: Appreciative inquiry, intra-institutional communication, public relations

\section{Introduction}

Communication not only forms the basis of a sustainable society but also it is a means that affects and shapes the behaviour of all kinds of organisms functioning in this society. For this reason, groups that come together so as to attain certain goals within a society transform into organizations and institutions. Key to their success in attaining their goals is their study on communications within and outside the institution. According to Gordon Lewis, creating a positive image outside the institution is only possible through a positive image created in the minds of the employees. A harmony between personal and institutional goals is provided through organizing the relationships within the organization via an intra-institutional communication. Intra-institutional communication enables the employees to understand the goals and purposes of the business better and this leads them to work more efficiently for institutional purposes; in addition, wellplanned communication studies make the employees have more authority and more roles within the institution which results in the development of an environment based on trust. Intra-communication studies are not only vital for institutional purposes but also for the development of healthy structures and for the prevention of problems within the institution.

\footnotetext{
${ }^{1}$ Presented at the ICSER-International Conference on Social Sciences and Education Research, October 29-31 October 2015, Turkey, Antalya

${ }^{2}$ Asist. Prof., University of Gaziosmanpaşa, Niksar School of Applied Science, Department of Public Relations and Advertising, seyfi.murat@gmail.com

${ }^{3}$ Ph.D., Candidate, Marmara University, Department of Public Relations, denizguvenn@gmail.com
} 
Seyfi, M., Güven, D. (2015). Appreciative inquiry as a means of intra-institutional communication. International Journal of Social Sciences and Education Research, 1 (1), 122-130.

With the effects of globalization, organizations are now striving to survive in a hyper-rivalry environment. For people who are living under an intense message bombing with messages coming from both their institutions and social life, receiving messages and providing feedback have become rather difficult. For this reason, institutions need to develop new methods and techniques in intra-institutional communication studies, thereby reaching their goals. In this regard, with its goals and outputs, the appreciative inquiry methodology is quite close to intra-institutional communication studies. Due to its humane and organic construction, this methodology has an effective structure that can exhibit all kinds of potentials of organizations. In this study, the community between the outputs of intra-institutional communication studies and implementations of appreciative inquiry has been investigated and suggestions were made for the use of this methodology in intra-institutional communication studies.

\section{Intra-institutional communication}

The internal communication system of an organization is the centerpiece of the organization's perfect public relations activities. According to Redding and Tompkins, the first organizational communication theories are neither exactly scientific nor academic. Rather, these are studies drawn up as prescriptions for institutions. In other words, traditional rhetoric has been applied to institutional conversation. To theorize about the subject, scientists who are interested in organizational communication have utilized positivist sciences, interpretive social sciences and critical approaches. By the use of relevant empirical, interpretive, qualitative methods in this way, organizational communication has taken its current form as an academic discipline (Grunig, 2005: 557574). Organizational communication provides a communication bridge between the internal and external environment of the organization. For this reason it enables a flow between all values of the organization (Glueck, 1980: 564). The communication studies built by the organization aimed at any kind of internal target group are about intra-institutional communication. With its basic definition, intra-institutional communication, which in terms of institutions finds meaning in the words productivity, profit, positive image and reputation, in terms of the employee signifies belonging, regard and involvement in the decision-making process (Baltaoğlu, 2012: 523). Intrainstitutional communication is a tool that provides balance within the organization. Intra-institutional communication plays an active role especially in the determination of hierarchy and establishment of authority within the institution. Thus, an environment of trust is ensured within the institution and free circulation of information arises (Tutar, 2003: 117). Intra-institutional communication enables employees to comprehend the goals and purposes of the organization better thereby enabling them to endeavor for the realization of these purposes and encourages the employees thereby enabling the birth of free opinions that will add value to the institution (Foltz, 1981: 9). The purposes of intra-institutional communication have been listed by Varol as below (Vural, 2005: 149-150);

- Giving information about the work and procedures, and in this way enabling work and skill education

- Ensuring that the employees know the purposes and policies of the institution

- Providing information and feedback to the management by encouraging innovation and creativity, relying on the experience, skill and mind of the personnel, and motivating the personnel in this respect

- Enlightening the personnel about the activities of the institution, important events and accomplishments 
Seyfi, M., Güven, D. (2015). Appreciative inquiry as a means of intra-institutional communication. International Journal of Social Sciences and Education Research, 1 (1), 122-130.

- Ensuring a bilateral symmetrical communication between managers and employees

- Developing the representational skills of the personnel during and outside of work

- Giving information about social and economic issues of the institution and solving the problems of the personnel, in addition, revealing the emotional and conflicting problems within the institution and offering solutions

- Enabling information flow between the management and personnel regarding advancement opportunities within the institution and future expectations

- Trying to create and maintain an organizational climate, culture and identity

In order to achieve these purposes, organizations must engage in activities that support intrainstitutional communication. According to Seitel, for the organizations to develop communication with their employees they need to investigate the attitudes of employees regularly, be consistent, sincere, innovative and they need to personalize communication (Seitel, 1992: 390-393). However there are some obstacles regarding the development of intra-institutional communication. These obstacles may be listed under the following titles (Tutar, 2003: 155-166);

- Constructive Obstacles to Organizational Communication: Liberating communication in institutions completely will cause much confusion. For this reason, some obstacles need to be put in the way of liberated communication. Selectivity in information flow will directly effect the efficiency of communication. Therefore social and official rules have to be established in communication.

- Destructive Obstacles to Organizational Communication: There are many destructive obstacles against efficient communication. These obstacles may be categorized as inconsistency, lack of confidence, information overload, status, age, gender, semantic factors, psychological factors, managers with no consideration for democratic principles, communication filter, negative attitudes of managers.

- Channel Obstacles to Organizational Communication: These are physical and technological obstacles, meanwhile they can also have socio-psychological properties.

- Technical Obstacles to Organizational Communication: Especially with the computer becoming an important part of institutional functioning and a fundamental tool in communication, technical obstacles began to emerge more frequently. The main problems here are obstacles such as encryption, transmittion of messages, the channel used, feedback and decryption during the communication process.

- Physical Distance: As contemporary institutions grow, they also become more complex. In intra-institutional communication, messages reach their targets passing through various positions. For this reason, the longer the process and the road the harder the communication might get.

- Time Pressure: Both within the institution and in institutional activities there is an ever increasing competitive environment. For this reason, the use of both personal time and institutional time are fairly important. Not having enough time in intra-institutional communication is one of the biggest obstacles to communication.

- Interruptions: The communication chain can be broken due to many reasons from interpersonal communication to institutional communication. The most essential way for this issue is to acknowledge the obstacle and develop solutions.

- Difference in Status and Hierarchy: Interpersonal status differences is an important phenomenon that determines the direction of interpersonal communication. People generally like to 
Seyfi, M., Güven, D. (2015). Appreciative inquiry as a means of intra-institutional communication. International Journal of Social Sciences and Education Research, 1 (1), 122-130.

communicate with others who are either in equal status or higher status. This creates a communication obstacle based on status.

- Organizational Stress: Organizational policies, structural properties of the organization, physical conditions and organizational processes cause organizational stress. Organizational stress unavoidably hinders intra-institutional communication as well and puts up resistance against the resolution of problems.

\subsection{Methods of intra-institutional communication}

As will be seen, there are many factors that hinder intra-institutional communication. Various methods are used for overcoming these obstacles and conducting information flow within the institution in a healthy manner. These methods may be summarized as follows;

Although they look as if they are basically prepared for an external target group, institutional publications are also an important part of intra-institutional communication. Within this process, where institutional promotion is conducted formally, the employees of the institution take nourishment from this communication process informally. For this, an autonomous institutional editorial staff, independent from the management, must be on duty (Okay and Okay, 2012: 271-274). Lots of institutional information such as service announcements for employees and personnel news are shared transparently by notice boards, which are highly trustworthy. The important thing here is, after being acknowledged by the institution personnel and managers, placing the notice boards in locations with heavy traffic where they will draw the attention of the personnel (Baltaoğlu, 2012: 534-535).

Within institutional structures audiovisual and inscribed aids such as management newspapers, brochures, handbooks, notices, circular notes, notice boards, reports, photographs, films, slides, videos, letters and telephones; also, verbal communication aids such as bilateral discussions, meetings, conferences and seminars are widely use (Sabuncuoğlu, 1996: 82). Besides institutional publications, face-to-face communication is also quite important for intra-institutional communication. Face-to-face communication and feedback programs constitute a wide range from communication taking place between two people to organized meetings. Although certainly there is a necessity for an information flow from top to bottom carried out by various communication methods, higher demand from employees have manipulated many institutions to implement programs for receiving feedback. (Baltaoğlu, 2012: 538).

It is clear that in intra-institutional communication not only individual influences but also collective activities carry importance. New media practices gradually popularizing in our day have many components at this point. With the new media, socialization, information flow, discussion, motivation, education, cultural development, cultural sharing, entertainment and integration may be provided within the institution (Dündar and Özel, 2012: 107). With the transformation it underwent in the new media order, the concept of intra-institutional communication has introduced many concepts acknowledged by the managers such as Institutional Guidance Management, Instant messaging, Sending Notices, etc. (http://kobitek.com/, 10.10.2015). Besides the New Media, institutions establish intra-institutional communication chains by creating their own networks. Established for the sharing of information within the bodies of institutions, Intranet is the connecting of the computers, local networks and wide area networks within the institution. Usually large companies ensure many intra-institutional communication and activities owing to these Intranet networks. Many activities such as document distribution, education and orientation, service 
Seyfi, M., Güven, D. (2015). Appreciative inquiry as a means of intra-institutional communication. International Journal of Social Sciences and Education Research, 1 (1), 122-130.

and support, relations with suppliers and forming of new documentation systems are conducted in the Intranet environment. Extranet, on the other hand, is a network where Intranet's technical infrastructure is used and which is set up only by identified people. Intranet and Extranet generate a solution to the time and location problem by eliminating distances (Baltaoğlu, 2012: 107).

When we look at intra-institutional communication tools we see that many of them are used for the same purposes. However, in the competitive environment which has been increasing with globalization, the development of new communication methods and techniques have become a necessity to reach the target group. Within this context, humane methods that can be conducted face to face or through internet can be utilized. Within this scope, the Appreciative Inquiry method can be seen as a new method for reaching intra-institutional communication purposes.

\subsection{Appreciative inquiry}

When David Cooperrider was a doctorate student in 1979, he started conducting face to face meetings with leaders regarding governance and processes. Professor Srivatsva was impressed by Cooperrider's focus on success stories rather than problematic stories, thus he supported him, and as a result they developed the Appreciative Inquiry methodology to be used in the development of people and organizations (Bushe, 2012: 8). The concept of Appreciative Inquiry passes as AI in the business and academic worlds. The concept is derived from the English word Appreciation, which constitutes its root, and it is used in the meanings of valuing, unearthing others' good features, feeling pleased. The second part of the concept, Inquiry, corresponds to researching and analyzing. Although the concept was born in the year 1980, it was implemented in the business world and presented in an organized way from 1987 onwards. In those years, the approach was subject to literature as Positive Management, while today it is used prevalently by communication experts worldwide under the name Appreciative Inquiry. (Yurdakul, 11.10.2015). The first textbook about Appreciative Inquiry was prepared and printed by Sue Hammond and Cathy Royal in the year 1998 (Watkins and Mohr, 2001: 20). This theory which emerged in 1979 and reached our day, consistently developed and renewed itself in the course of time. For this reason, the concept of Appreciative Inquiry has gained an organic structure.

At the heart of Appreciative Inquiry lies the tendency to diverge from classical problem solving methodology. Because the old methodology is far from motivating. It looks for a problem, criticises and afterwards tries to focus on the solution. On the other hand, Appreciative Inquiry abandons problem-searching, and with the positive feedback method it focuses on unearthing the best, the most successful stories imprinted on the memories of individuals and institutions. Individual and institutional achievements serve as basis for the configuration of the collectively desired future. The Classical and Appreciative Inquiry approaches may be compared as below (Yurdakul, 2015); 
Seyfi, M., Güven, D. (2015). Appreciative inquiry as a means of intra-institutional communication. International Journal of Social Sciences and Education Research, 1 (1), 122-130.

Table 1. Two different perspectives on the change and structuring processes

\begin{tabular}{l|l}
\hline Traditional Approach & Appreciative Inquiry Approach \\
\hline Focus on lacks and problems & Focus on pluses and potential \\
\hline $\begin{array}{l}\text { Determination and identification of problems } \\
\text { and needs }\end{array}$ & $\begin{array}{l}\text { Focus on the process in which the best perfor- } \\
\text { mance is given }\end{array}$ \\
\hline Examines the reasons & Focuses on the success \\
\hline Aims to find solutions to problems & $\begin{array}{l}\text { Tries to find good features that must be urged } \\
\text { upon }\end{array}$ \\
\hline Plans the things to be done & Shapes its destiny, imagines the ideal situation \\
\hline $\begin{array}{l}\text { Basic assumption: Our job is to overcome the } \\
\text { main problems }\end{array}$ & $\begin{array}{l}\text { Basic assumption: Our job is to reveal our po- } \\
\text { tential and achieve the best performance. }\end{array}$ \\
\hline
\end{tabular}

For the theorization of Appreciative Inquiry, Cooperrider and Srivastva have defined its dimensions as follows (Cooperrider \& Srivastva, 1987: 184);

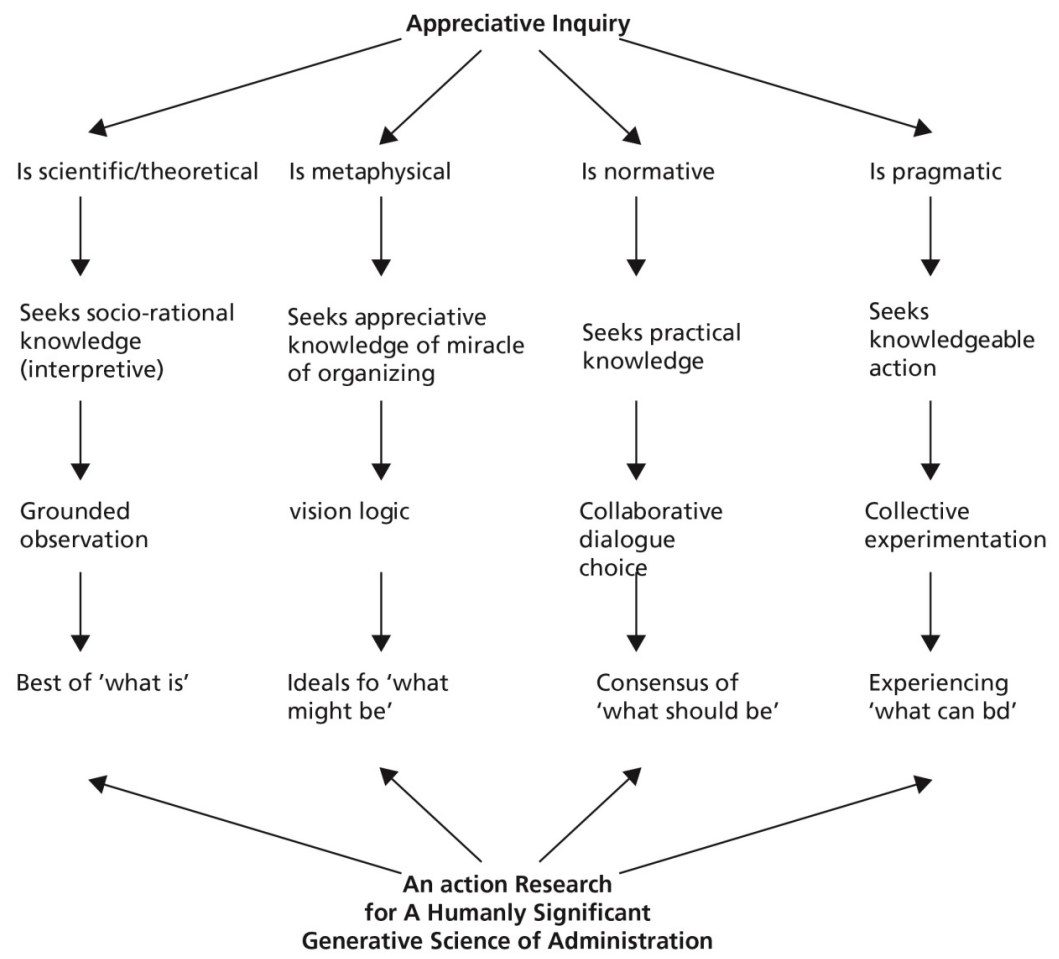

In the above figure, in order to ensure that appreciative inquiry is theorized, Cooperrider and Srivastva have dimensioned the subject theoretically, normatively, metaphysically and pragmatically. With the investigations made and future pursuits, a very important operational research model has been set for administrative science.

The appreciative inquiry methodology tries to reveal the best experiences of the organization members through various questions. Within this scope, the below questions may be asked to the group members (http://theducklows.ca, 08.09.2015);

-What is your experience within the organization when you felt most successful? 
Seyfi, M., Güven, D. (2015). Appreciative inquiry as a means of intra-institutional communication. International Journal of Social Sciences and Education Research, 1 (1), 122-130.

- What is the best connection between your organization and you? What are the things that prevent you from breaking lose from your organization?

- How do you cope with it when you remain under stress and pressure within the organization?

-Were there any positive changes regarding yourself within the organization?

- Now suppose that all problems your organization is having have been resolved and imagine how your organization would be in this condition?

Appreciative inquiry is the revealing of the success stories of the individuals and the institution. In a way, with appreciative inquiry organizational storytelling is done collectively. The first step of appreciative inquiry is exploration. This is the part where individuals tell their stories, thus laying the foundation (Simmons, 2007: 36). The foundation of appreciative inquiry, the exploration stage, can be realized by revealing the stories within the institution. Bilateral or group discussions are not the only way for this. Other communication tools such as photographs, letters and social media can also be used (Langer and Thorup, 2006: 371-396). The important thing here actually is that appreciative inquiry is allowed to create the story of the institution. Meaning, the internalizing of a story in which achievements and positive experiences are placed in the center and a perfect future is written by group members.

\subsubsection{The process of appreciative inquiry}

The Appreciative Inquiry model has been categorized in different ways in accordance with the target group and the geography it is used in and by this means has become an organic structure. For example, for small groups the SOAR model was developed. The stages of the SOAR model are;

Strength: What foundations can we build upon / What can we ground on?

Opportunities: What do our stakeholders want?

Aspiration: What do we really consider important?

Results: How will we be able to tell that we have succeeded?

Another quite popular model which is a little more developed than SOAR is the 5I model. The stages of this model are (Stavros \& Hincrichs, 2009);

Initiate: Deciding to use the SOAR model

Inquire: Searching of foundations - asking of questions

Imagine: Which opportunities are possible

Innovate: Touching on subjects that are really important and turning possibilities into opportunities

Inspire to Implement: Realize and measure the results

The most popular and widespread process of the appreciative inquiry model is called 4D; consisting of discovery, dream, design and destiny processes. The 4D model was developed in Zimbabwe in 1997 by members of a non-governmental organization engaged in activities for the protection of children. Later, Whitney and Trosten-Bloom spoke of a fifth dimension which they named Definition, arguing that Appreciative Inquiry consists of five dimensions. 
Seyfi, M., Güven, D. (2015). Appreciative inquiry as a means of intra-institutional communication.

Discovery: The ones working at this stage are directed with various questions for them to tell their success stories within the institution. For example, when did you feel most successful in the institution? Where, when and how this success was realized are questioned and the best process for success is discovered. Members of the institution prefer to learn success stories as positive potentials rather than learning the problems of the organization, the forgotten activities or the statistics (Watkins and Mohr, 2001: 43).

Dream: In the meetings organizations have with their stakeholders, they generally focus on the position of the organization and the relation it has with its rivals. However, here stakeholders are directed to dream about the future and this is done with practical and productive activities (Watkins and Mohr, 2001: 44).

Design: The design process provides the social architecture and the production of micro attraction processes of the organization. This way, the process which will carry the organization into the future is scrutinized. Thus, short and long term goals are revealed (Watkins\&Mohr, 2001).

Destiny: Defined as Delivery by Cooperrider, this stage includes too many details regarding classical management systems, therefore eventually it has been changed as Destiny. According to Busche it is the most controversial stage of Appreciative Inquiry. In brief, in this stage new policies are developed for the dreamed future (Richards, 2012: 24).

\section{Conclusion}

Together with globalization, institutions have entered a serious competition environment and correspondingly have had to survive under intense stress. The complex problems that come up in the institution cannot be resolved by simple motivation studies like the carrot and stick approach anymore. For this reason, in order to improve their intra-institutional image, which constitutes the center of their outward image, institutions need to develop new methods and techniques. For a more profitable production and also due to social accountability, managements which are aware of the fact that the human factor is at the centre of modern modes of production, use employee oriented communication methods in their relationships with their employees. The appreciative inquiry methodology enables the employees to develop their stories which will ensure them to embrace the institution they are working in, without domineering people or overwhelming them with questions and examples; thus it can be defined as a new intra-institutional communication method. The relations between appreciative inquiry, which is a more democratic and humane method, and the results of intra-institutional communication is as below;

- With appreciative inquiry, interpersonal information exchange takes place.

- In implementation of the methodology of appreciative inquiry, thanks to the fact that experiences of individuals are in the forefront instead of their titles, information flow is not hindered and everyone freely shares their experiences and stories.

- With appreciative inquiry, the perfect organization is imagined and a road map is determined for this. This is directly related to the maintaining of organizational commitment which is the goal of intra-institutional communication and one of its outputs.

- With the gathering and accumulation of experiences acquired during appreciative inquiry, empowerment is actualized, which is one of the most important outputs of intra-institutional communication. 
Seyfi, M., Güven, D. (2015). Appreciative inquiry as a means of intra-institutional communication. International Journal of Social Sciences and Education Research, 1 (1), 122-130.

- By suggesting individuals to tell their stories and use these for sample cases, appreciative inquiry provides the strengthening of bonds between the institution and employee. This at the same time reveals the leadership skills that are tried to be reached through intra-institutional communication.

- One of the most important emphasises of intra-institutional communication is the identification and solution of problems like mobbing within the institution. These problems are identified at the Discovery stage of the appreciative inquiry method and solution suggestions may be developed at the Dream stage.

\section{References}

Bushe, G. (2012). Foundations of appreciative inquiry: History, criticism and potential, AI Practitioner, 14,1

Cooperrider, D.L. \& Srivastva, S. (1987). Appreciative Inquiry in Organizational Life. In R. Woodman \& W. Pasmore (eds.) Research in Organizational Change and Development, Greenwich, CT: JAI Press, Volume 1.

Dündar P. and Özel K.E. (2012). Kurum içi iletişimin kaliteye olan etkisi: Yeni İletişim Teknolojilerinin Kurum İçi İletişimin Kalitesine Olan Etkisini İncelemeye Yönelik Bir Araştırma, ODÜ Sosyal Bilimler Dergisi, volume 3, number 6.

Foltz, G. R. (1981). Communication in Contemporary Organization Inside Organizational Communication, Edited by: Carol Reuss, Donn Silvis, New York:Longman

GLueck, F. W. (1980). Management, The Dryden press, Hindsdak, Illionis.

Grunig, E. J. (2005). Halkla İlişkiler ve İletişim Yönetiminde Mükemmelik, Rota Yayınları, İstanbul.

Langer R. \& Thorup S. (2006). Building Trust in Times of Crisis: Storytelling and Change Communication in an Airline Company, Journal of Corporate Communications, Vol.11 no.4.

Okay A. and Okay A., (2012) Halkla İlişkiler Kavram stratejileri ve Uygulamaları, İstanbul: DR Yayınları

Peltekoğlu, F. B. (2012). Halkla Illişkiler Nedir? (7th edition). İstanbul: Beta Yayınc1lık

Richards, J., (2012). Storytelling in Appreciative Inquiry Postgraduate Thesis, East Tennessee State Un.

Sabuncuoğlu Z. (1996). İşletmelerde Halkla Iliş̧kiler, Bursa.

Seitel F. P. (1992). The Practice of Public Relations, New York: Macmillan Publishing Company.

Simmons, A. (2007). Whoever tells the best story wins. New York, NY: Amacon

Stavros, J. \& Hinrichs, G. (2009). The Thin Book of SOAR: Building Strengths-Based Strategy. Bend, OR: Thin Book Publishing.

Tutar, H. (2003). Örgütsel İletişsim (1st edition). Ankara: Seçkin Yayıncılık

Vural, Z.B.A. (2005). Kurum Kültürü (2nd edition) İstanbul: İletişim Yayınları

Yurdakul, S., http://www.ikedaconsulting.com/documents/Olumlu_Sorgulama-Makale.pdf

Watkins, J.M. and, Mohr, B.J. (2001). Appreciative Inquiry: Change at the Speed of Imagination JosseyBass/Pfeiffer, San Francisco, CA United States.

http://kobitek.com/kurum-ici-iletisim-sirketler-icin-neden-onemlidir

http://theducklows.ca/downloads/AISystemsChange.pdf

http://www.wisdompage.com/AEPL/appreciative_inquiry.pdf 